\title{
The specific features of the Getic fortifications in the Middle Dniester region (the Saharna and Horodiște-Țipova micro-zones)
}

Aurel Zanoci, Mihail Băț

\begin{abstract}
In the Middle Dniester region, as a result of field investigation, surveys, and archaeological researches 40 fortifications and 70 open settlements attributed to the Getic communities of the $4^{\text {th }}-3^{\text {rd }}$ centuries BC were discovered. In recent years, increased attention has been paid to the research of fortifications in the Saharna (16 sites) and Horodişte-T,ipova ( 7 sites) micro-zones. Based on field investigations and archaeological research, it has been observed that the defensive system of the fortifications in this region has some specific features, which are not attested in the rest of the Getic fortresses. Among these are the so-called "bastions", which can be divided into two types according to the place of arrangement within the defensive system: bastions placed in front of the entrance gates, and "bastions" located on the perimeter of the fortification. The erection of defensive constructions of the bastion type as additional elements of the fortifications denotes the fact that the Getic communities of the Middle Dniester region had a thorough knowledge of the military architecture.
\end{abstract}

Keywords: Middle Dniester region, Iron Age, Getae, fortifications, bastions.

Due to the favorable physical and geographic conditions (Ciobotaru 2014, 11-13; Revenco, Castraveț and Nicu 2016, 9-18), the southern part of the Dniester region (Fig. 1) has served as a living place for human communities since the earliest times, as evidenced by numerous archaeological sites. However, a real "demographic explosion" in this space (Fig. 3) is attested in the 4th-3rd centuries BC, which about 40 fortifications and about 70 open settlements are dated to (Kašuba, Haheu and Levițki 2000, 119-130; Zanoci and Băț 2011, 17-19, tab. 1; Zanoci, Niculiță and Băț 2015, 82-100; Niculiță, Zanoci and Băț 2016, 7, 329-374, tab. 4; Zanoci, Niculiță and Băț 2017, 7-46).

However, in the last years, the Getic sites concentrated in two distinct micro-zones of the Middle Dniester region - Saharna and Horodişte-Tipova were given special attention (Fig. 3); there were conducted systematic archaeological research, surveys, and wide-scale investigations. These have resulted in the publication of several articles (Niculiță et al. 2013, 219-292; Niculiță, Zanoci and Băț 2013, 295-314; Niculiță, Zanoci and Băț 2014, 235-252; Zanoci, Niculiță and Băț 2015, 82-100 etc.) and monographs (Niculiță, Zanoci and Arnăut 2008; Niculiță, Zanoci and Băț 2016). 


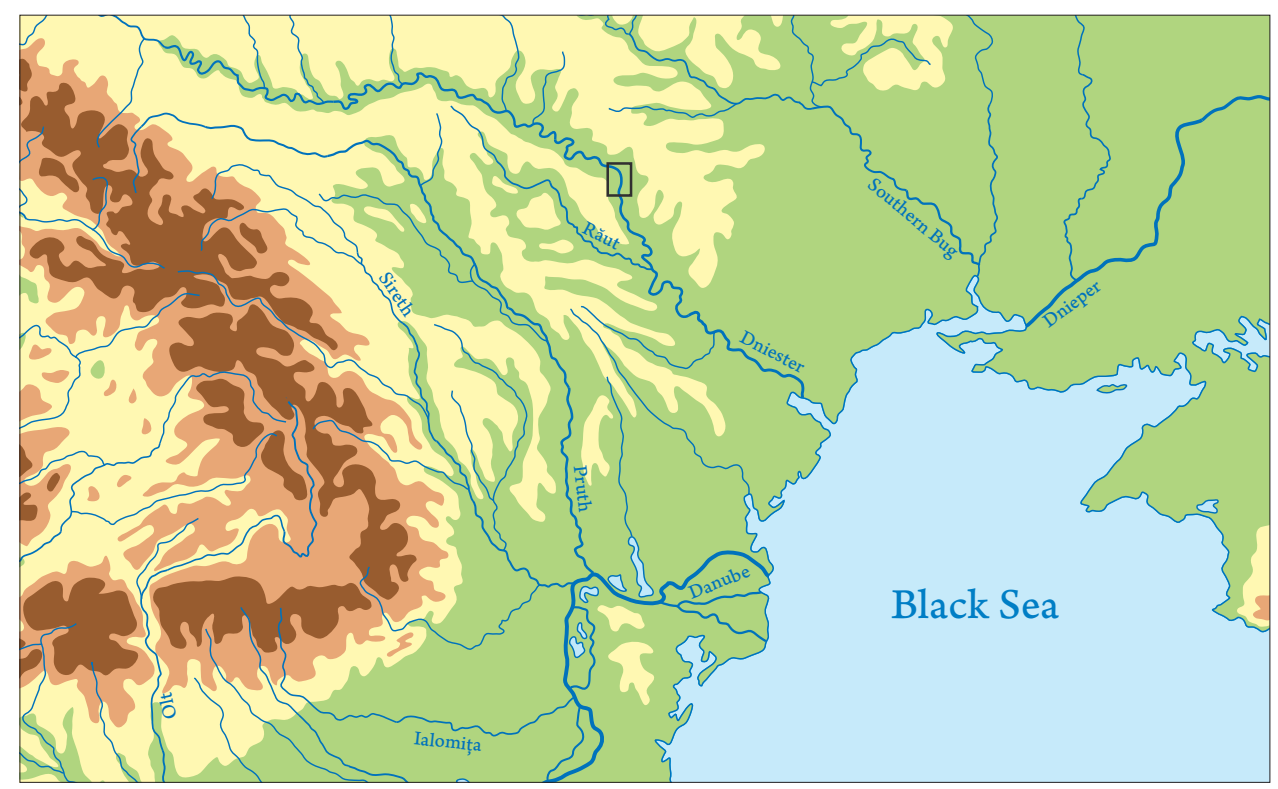

Fig. 1. Location of the Middle Dniester region.

The Saharna micro-zone is a strip of land with a width of about 2.0-4.5 $\mathrm{km}$, which extends along the right bank of the Dniester River for about $8.5 \mathrm{~km}$, between the villages of Stohnaia (in the north) and Buciuşca (in the south). The Dniester River bank in this region is rather steep and has a relative altitude of about $80-130 \mathrm{~m}$ from the riverbed. The micro-zone is segmented by three gorges, which go from the Dniester riverbed and continue towards the interior of the territory, thus forming a series of promontories favorable for the location of the fortresses (Fig. 2; 4). As a result of field investigations, surveys and archaeological research, 16 fortifications and 14 open settlements have been documented in this area, which date to the $4^{\text {th }}-3^{\text {rd }}$ centuries BC (Fig. 4) (Niculiţă, Zanoci and Băţ 2016, 388-396).

The Horodişte-T,ipova micro-zone, with an area of about $6 \mathrm{sq}$. $\mathrm{km}$, is lo-

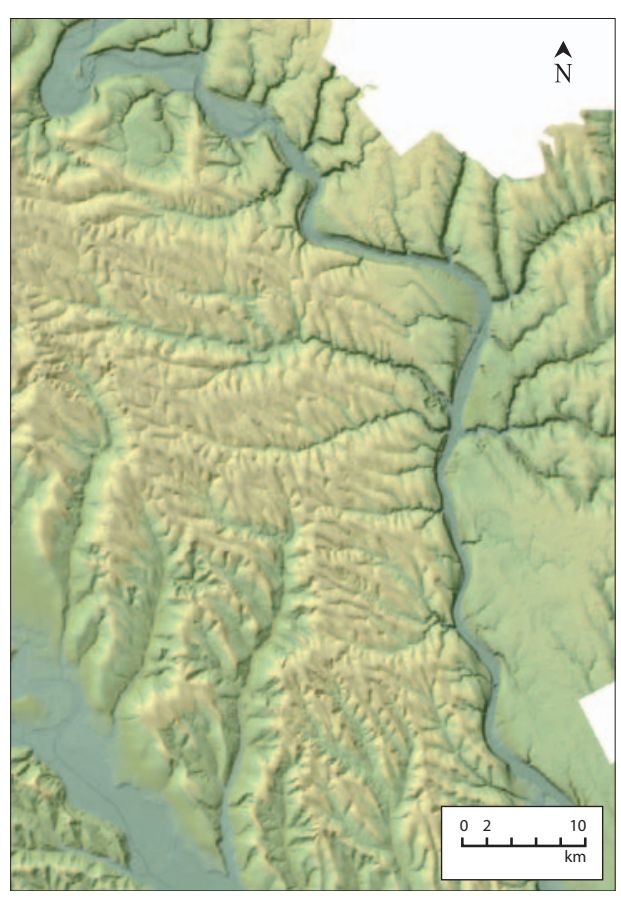

Fig. 2. Relief of the Middle Dniester region (after https://www.moldova-map.md/). 


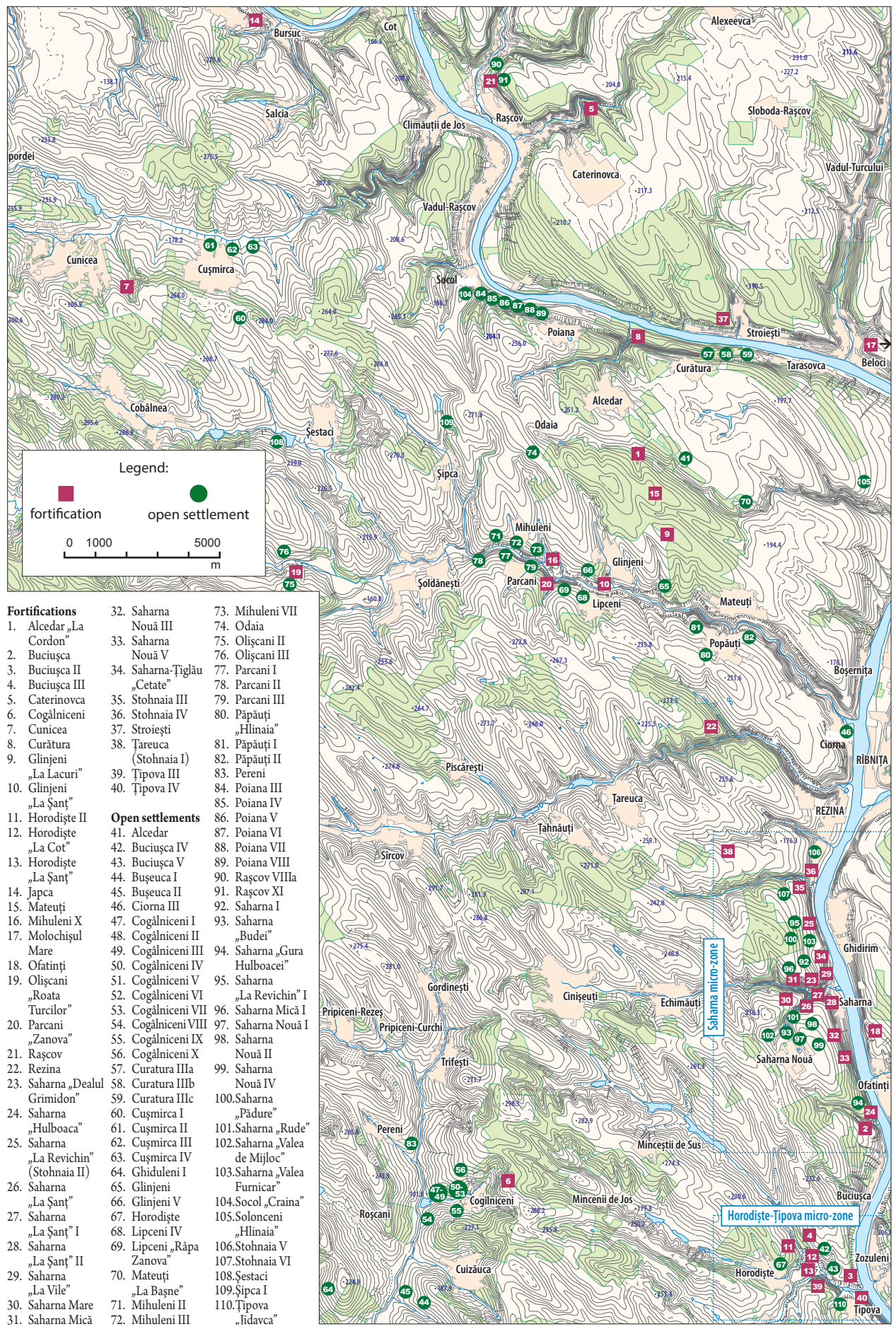

Fig. 3. Spreading of Getic sites in the Middle Dniester region $\left(4^{\text {th }}-3^{\text {rd }}\right.$ centuries BC). 


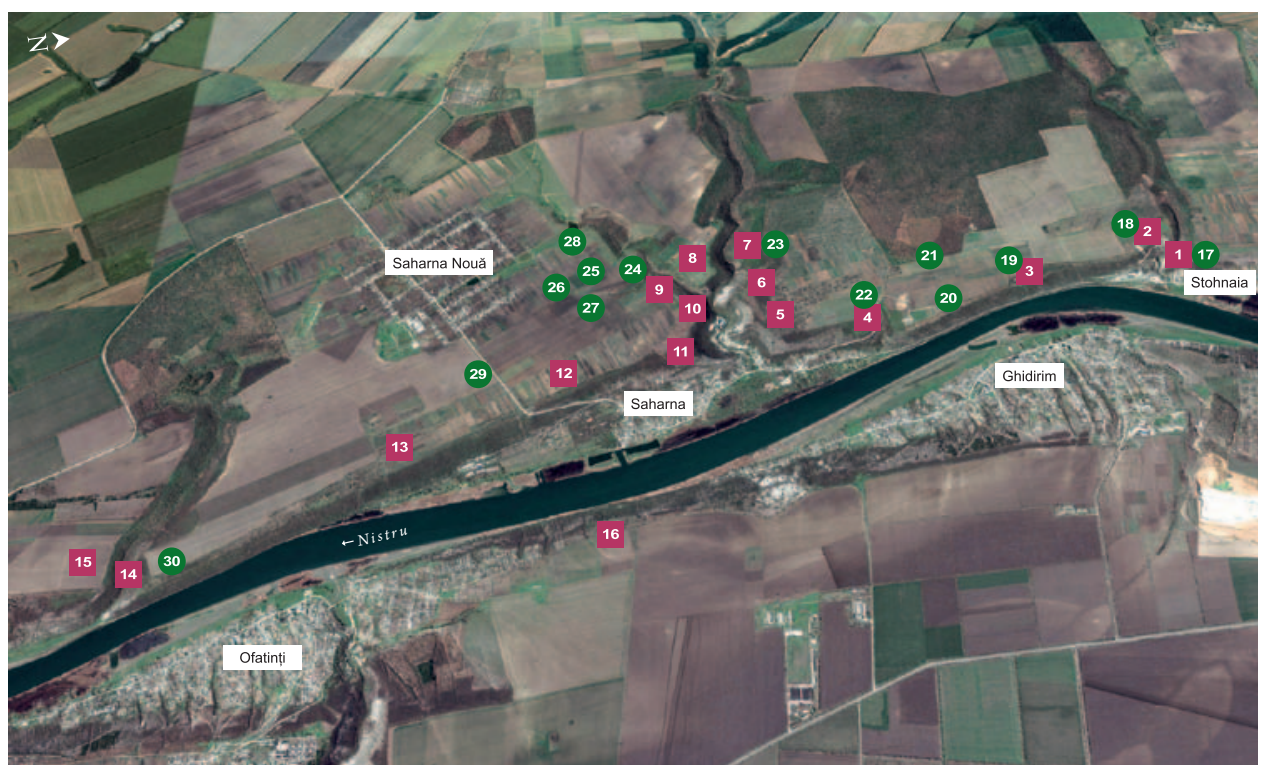

Fortifications:

1. Stohnaia IV; 2. Stohnaia III; 3. Saharna „Revechin”; 4. Saharna-Țiglău „Cetate”; 5. Saharna „La Vile”; 6. Saharna „Dealul Grimidon”; 7. Saharna Mică; 8. Saharna Mare; 9. Saharna "La Şanț”; 10. Saharna „La Şanț I"; 11. Saharna „La Şanț II”; 12. Saharna Nouă III; 13. Saharna Nouă V(?); 14. Saharna „Hulboaca”; 15. Buciuşca; 16. Ofatinți.
Open settlements:

17. Stohnaia V; 18. Stohnaia VI; 19. Saharna „Revechin I”; 20. Saharna „Valea Furnicar”; 21. Saharna „Pădure”; 22. Saharna I; 23. Saharna Mică I; 24. Saharna „Rude”; 25. Saharna "Budei”; 26. Saharna Nouă I; 27. Saharna Nouă II; 28. Saharna "Valea de Mijloc”; 29. Saharna Nouă IV; 30. Saharna „Gura Hulboacei”.

Legend: Saharna village $\square$ fortification $\square$ open settlement

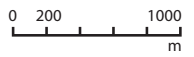

Fig. 4. Distribution of Getic sites in the Saharna micro-zone (orthophotomap after Google Earth Pro).

cated on the right bank of the Dniester at a distance of about $5 \mathrm{~km}$ to the south of the previous one. In this region the river bank is also steep and rises about 100-130 m above the surface of the water. The territory is segmented by a deep gorge with steep slopes, which starts from the river and continues north-east on a distance of about $1.5 \mathrm{~km}$ (Fig. 2; 5). Near the village of Horodişte the gorge branches, forming a network of canyons, which shape a series of promontories. As a result of the study of orthophotomaps, field surveys and archaeological investigations in this micro-zone, there were found an "agglomeration" of Getic sites consisting of seven fortifications and four open settlements (Fig. 5) (Niculiță, Zanoci and Băț 2014, 235-252; Zanoci, Niculiță and Băț 2015, 82-100).

Within these micro-zones, special attention was paid to studying the defensive system of the fortresses. At all fortifications, the remains of the defensive lines were visually investigated; their outline was fixed with the GPS. In the most of them (Saharna Mare, Saharna Mică, Saharna "La Şanț”, Saharna "La Vile", Horodişte "La Cot", etc.) excavations of defensive structures were carried out. Thus, it was observed that the defensive system of the Getic sites in the Saharna and Horodişte-Țipova micro-zones does not differ, in major terms, 


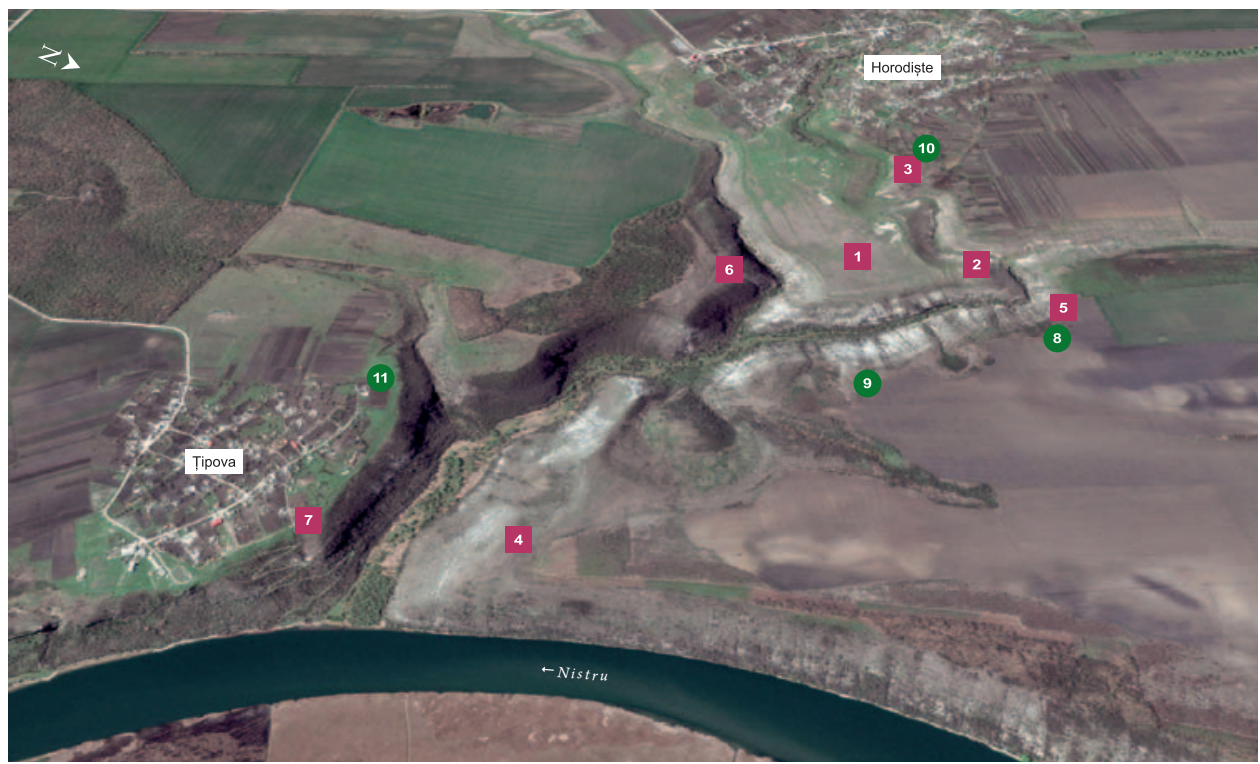

Fortifications:

Open settlements:

1. Horodişte "La Cot”; 2. Horodişte „La Şanț”; 3. Horodişte II; 4. Buciuşca II; 5. Buciuşca III; $\quad$ 8. Buciuşca IV; 9. Buciuşca V; 10. Horodişte; 11. Țipova „Jidavca” 6. Tipova III; 7. Tipova IV

Legend: Țipova village $\square$ fortification $\square$ open settlement

$0 \quad 100$ $\stackrel{500}{\mathrm{~m}}$

Fig. 5. Distribution of Getic sites in the Horodiște-Țipova micro-zone (orthophotomap after Google Earth Pro).

from that of the fortifications from other territories populated by the Getic communities (Zanoci 1998, 32-63).

At the same time, there are also some specific features, which at the moment have not been seen at the fortifications in the neighboring regions.

Among the features is the presence of the so-called "bastions", which can be divided into two types according to the place of arrangement within the defensive system: "bastions" placed in front of the entrance gates and "bastions" located on the perimeter of the fortress.

\section{Bastions located in front of the entrance gates (Fig. 13)}

This type of construction has the form of a "horseshoe" and is characterized by large dimensions: from $27 \times 30 \mathrm{~m}$ to $40 \times 44 \mathrm{~m}^{1}$. Such constructions have been researched in the Getic hillforts of Saharna Mică and Saharna Mare.

The Saharna Mică fortification (Fig. 4; 5), with an area of about 0.7 ha, is located on a promontory with an altitude of about $125 \mathrm{~m}$ from the Dniester riverbed, formed by the bend of the left side of the "Valea Crac" gorge. On the west, south

1 The dimensions of the bastions are given from the middle (the highest point) of the "rampart". 

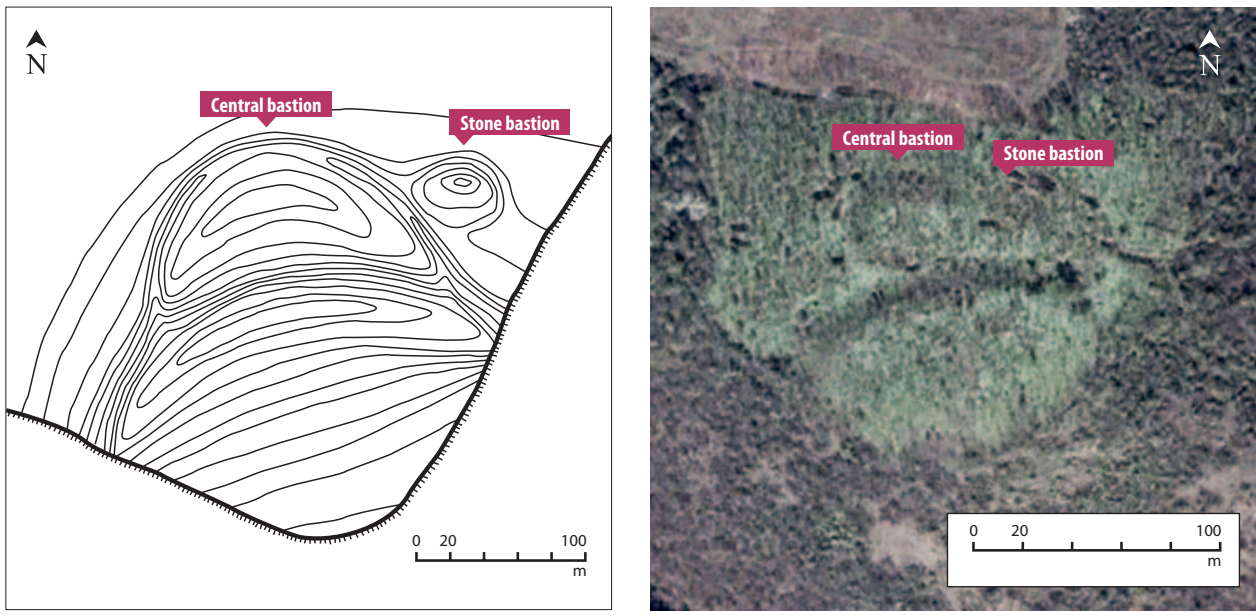

Fig. 6. Saharna Mică. Topographic sketch and orthophotomap (after Google Earth Pro).

and east, it was protected by abrupt, almost impregnable slopes of the promontory. The only accessible part, the northern one, was blocked with a rampart and an adjacent ditch, representing a slightly curved line with a length of approximately 160 $\mathrm{m}$. On the northern side, approximately in the central part of the defensive line, where the rampart is flattened (probably the place of the entrance gate), in front of the ditch, there was a horseshoe-shaped bastion with dimensions of approximately $40 \times 44 \mathrm{~m}$, which ends joined to the ditch of the fortress (Fig. 6; 13). At present, the "rampart" of the bastion has a base width of about $22 \mathrm{~m}$ and a height of about $3.6 \mathrm{~m}$ from the modern ground surface. As a result of the archaeological excavations, it was established that the "rampart" is the remains of a complex construction, such as a "wall", in the building of which wood, stone, and soils with different cohesion were used. Judging by the stratigraphy attested in the excavation, it can be assumed that this "wall" had a base width of about $11 \mathrm{~m}$ and was supported by frames of wooden beams, and in its filling there were compacted earth and stone (Niculiță, Zanoci and Băț 2016, 268-269, fig. 171, 184).

The second bastion was built in front of the defense line, on the northeastern side most exposed in the case of attacks from the north and east. The remains of the bastion ${ }^{2}$ at the time of the discovery were in the form of an elongated mound, on the surface of which limestone stones were noted (Smirnov $1953,6)$. The archaeological researches revealed the presence of a defensive construction of semicircular shape, in the construction of which a huge amount of stone was used. The bastion had an outer diameter of about $24 \mathrm{~m}$ and the inner one - of about $14 \mathrm{~m}$ (Fig. 6; 7). Its base was a stone wall made without

2 The bastion was discovered and researched by G. Smirnov in 1946-1947. 

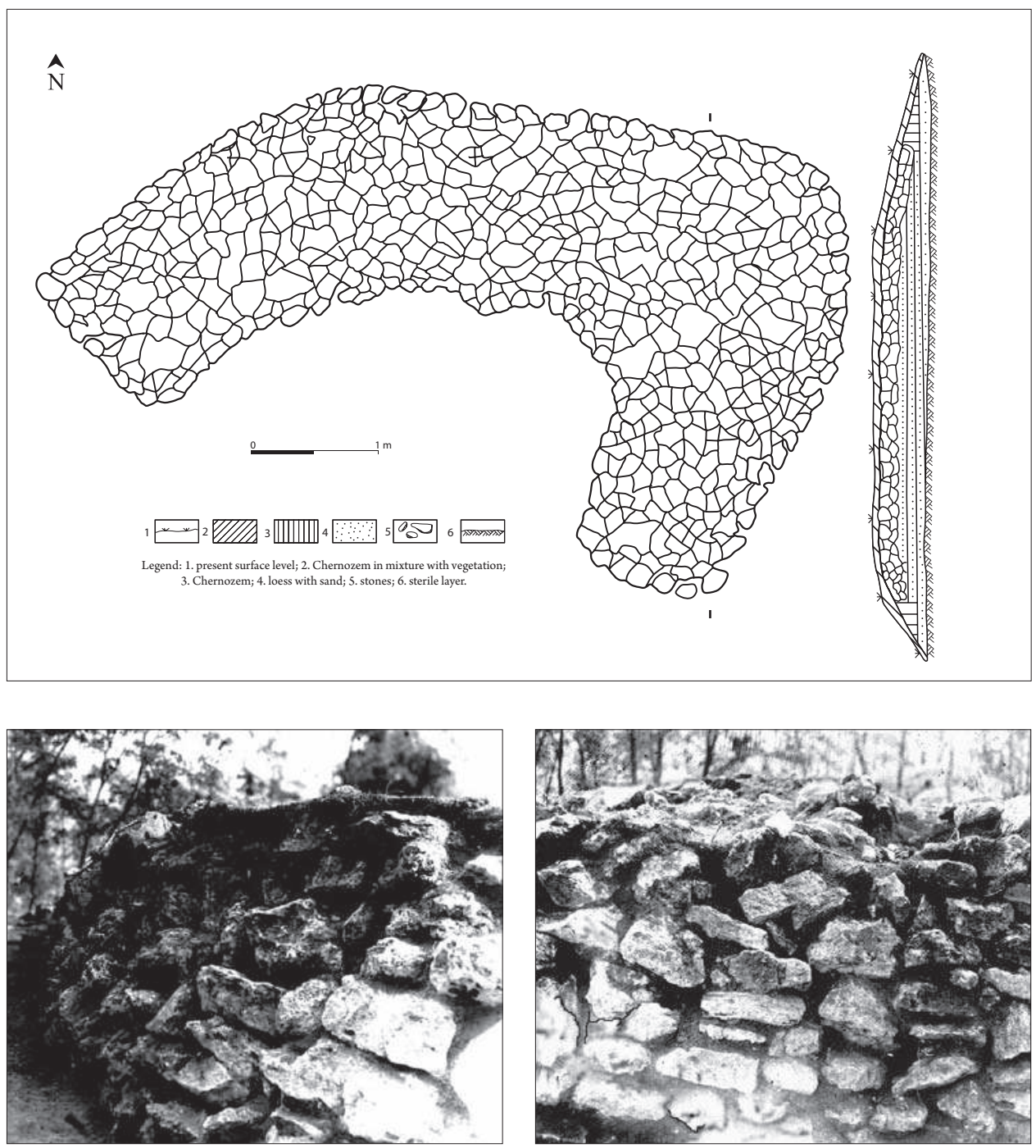

Fig. 7. Saharna Mică. Ruins of the stone bastion (after G. Smirnov and T. Arnăut).

mortar, of a width on the west side of about $6 \mathrm{~m}$, on the east - about 5-6 m, and on the north (front) side - about 7-9 m. Two to nine rows of limestone stones laid one over the other have been preserved from this construction (Fig. 7). Inside the bastion, but also over the ruins of the wall, there were traces of ashes, pieces of carbonized beams and fragments of burned clay. These finds allow the assumption that a wooden framework coated with clay was erected over the stone construction (Niculiță, Zanoci and Arnăut 2008, 25, fig. 2).

The Saharna Mare fortification was built on a promontory of an approximately trapezoidal shape, which is part of the high terrace $(130 \mathrm{~m}$ altitude from 
the riverbed) of the right bank of the Dniester (Fig. 4; 8). The area of the fortress of about 6 ha was surrounded by a defensive system, composed of several defensive elements. On the western side they consist of a "rampart" with an adjacent ditch with a length of about $385 \mathrm{~m}$. On the length of the "rampart", three interruptions were observed, one in the central part and two others at the flanks, which are probably former gateways. In front of these "interruptions" were built bastions, which had their own defense ditches in front of them.

The central bastion was shaped like a "horseshoe", with the dimensions of about $38 \times 43 \mathrm{~m}$ (Fig. 8-10). His "rampart" currently has a base width of about $23 \mathrm{~m}$ and a height of about $3.2 \mathrm{~m}$. As a result of the archaeological excavations it was established that "rampart" is the remains of a "wall" with a width of 6.8 $\mathrm{m}$ that consisted of a framework of beams arranged vertically and horizontally and filled with stones, gravel, and earth. In front of the "wall", separated by a berm with a width of about $2.7 \mathrm{~m}$, a ditch with a width of about $19 \mathrm{~m}$ and a depth of about 3.7 m was dug (Niculiță, Zanoci and Arnăut 2008, 96-97, pl. 5, photo 20-26).

Another bastion (Fig. 8-10) was placed in front of the gate on the southern flank of the fortress. It has a "horseshoe" shape with the dimensions of about $27 \times 30 \mathrm{~m}$. At present the "rampart" of the bastion has a width of about $18 \mathrm{~m}$ and a height of about $2.8 \mathrm{~m}$. As a result of the archaeological investigations it was found that the "rampart" is the remains of a "wall" with a width of about 6.8-7.0 $\mathrm{m}$ consisting of frames of wooden beams filled with stones, gravel, and earth. At a distance of about $2 \mathrm{~m}$ in front of the bastion, a ditch with a width of about $12 \mathrm{~m}$ and a depth of about $2.5 \mathrm{~m}$ was dug (Niculiță, Zanoci and Arnăut 2008, 92-96, pl. 6, photo 16-19).

The third bastion is in front of the gate on the northern flank (Fig. 8-10). Regretfully, it was not preserved, being destroyed in the 1950s during the construction of a road on the territory of the fortification. However, its existence is testified by a photograph made by G. Smirnov in 1946-1947 (Fig. 10).

Based on the location of the bastions of Saharna Mare and Saharna Mică, as well as on their configuration, it can be seen that access to fortifications was possible only by bypassing these buildings, which meant that the one who intended to enter the fortress was always exposed to the attack on the right side unprotected by a shield (Fig. 11-13). The defense of the gates with semi-circular bastions has a much older tradition and has been known in the Aegean area since the Bronze Age, such as, for example, at Aegina V (2300-2000 BC) (Ivanova 2008, 271, Taf. 1 ). Later, in the 1st century BC this way of defending the gates will also be reflected in the written sources: "Special pains should be taken that there be no easy avenue by which to storm the wall. The roads should 
$14 \mid$ PLURAL
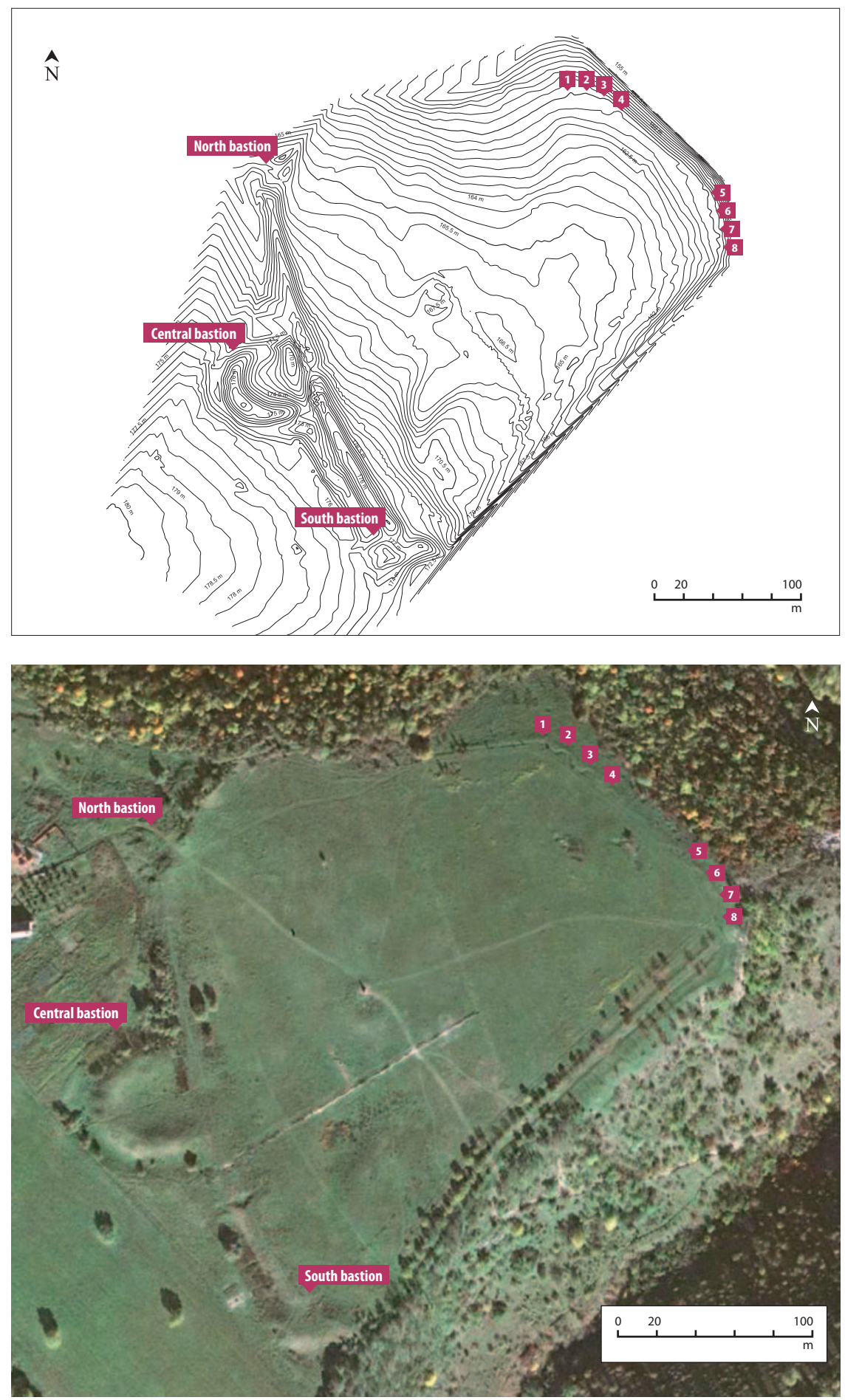

Fig. 8. Saharna Mare. Topographic map and ortophotomap (after https://www.moldova-map.md/). 


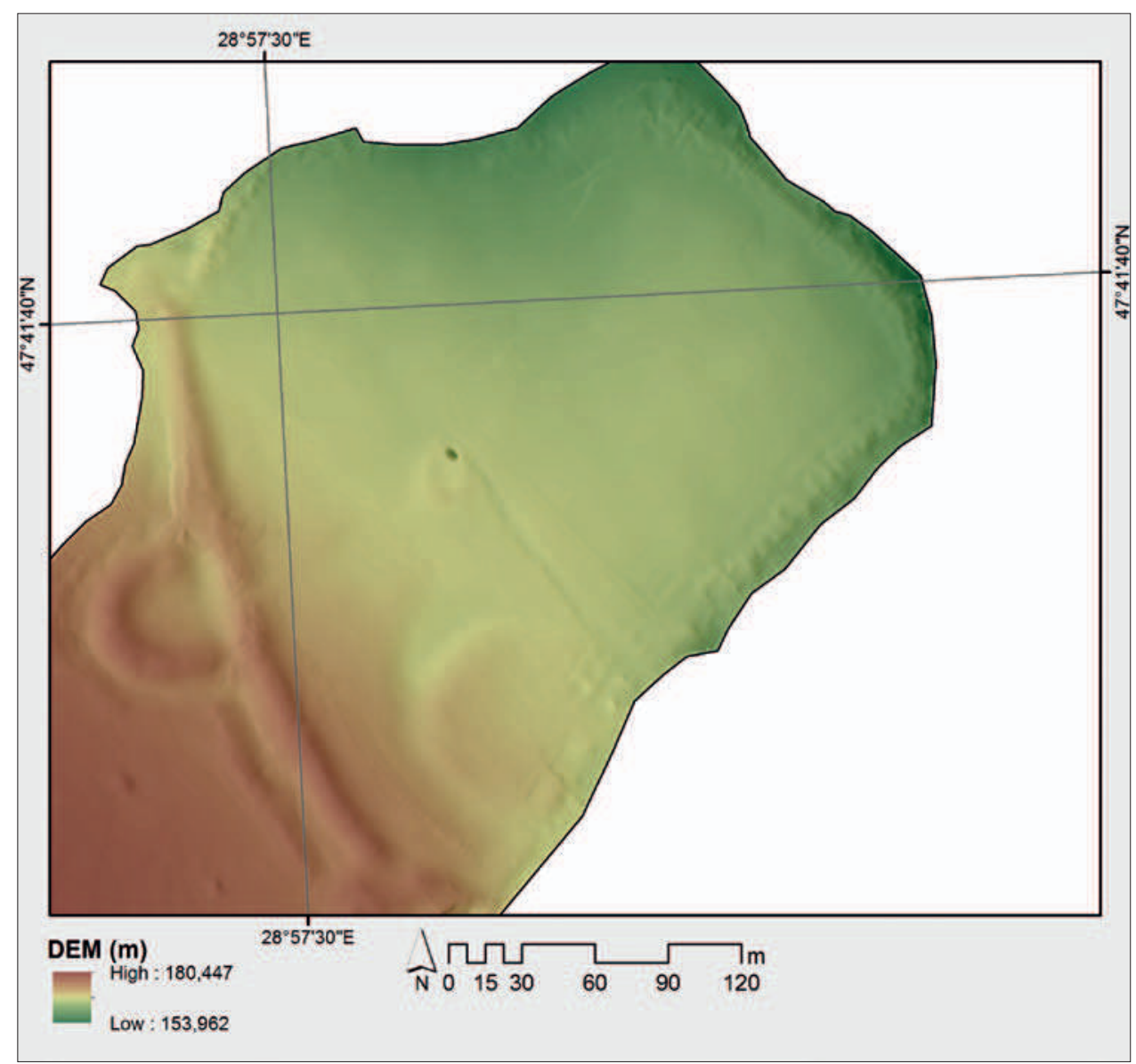

Fig. 9. Saharna Mare. Hypsometric map (after Asăndulesei 2016).

be encompassed at steep points, and planned so as to approach the gates, not in a straight line, but from the right to the left; for as a result of this, the right hand side of the assailants, unprotected by their shields, will be next the wall" (Vitruvius 1914, I, V, 2).

As mentioned above, the use of the semicircular bastions to defend the gates is something specific only for the Getic sites of the Saharna micro-zone. However, additional constructions that had the same predestination - the protection of the entrance gates, but of another configuration were attested in a small number of Getic fortifications of this period: Rezina (Zanoci, Niculiță and Băț 2016), Glinjeni "La Şanț” (Goltseva and Kashuba 1995, 6), Rudi "La Şanțuri” (Romanovskaia 1975, 29), Butuceni (Niculiță, Teodor and Zanoci 2002, 36), Orbeasca de Sus (Sîrbu and Trohani 1997, 516), Bucovăț (Sîrbu and Trohani 1997, 528-529), etc. For example, in the Middle Dniester region, at Glinjeni 
16 PLURAL

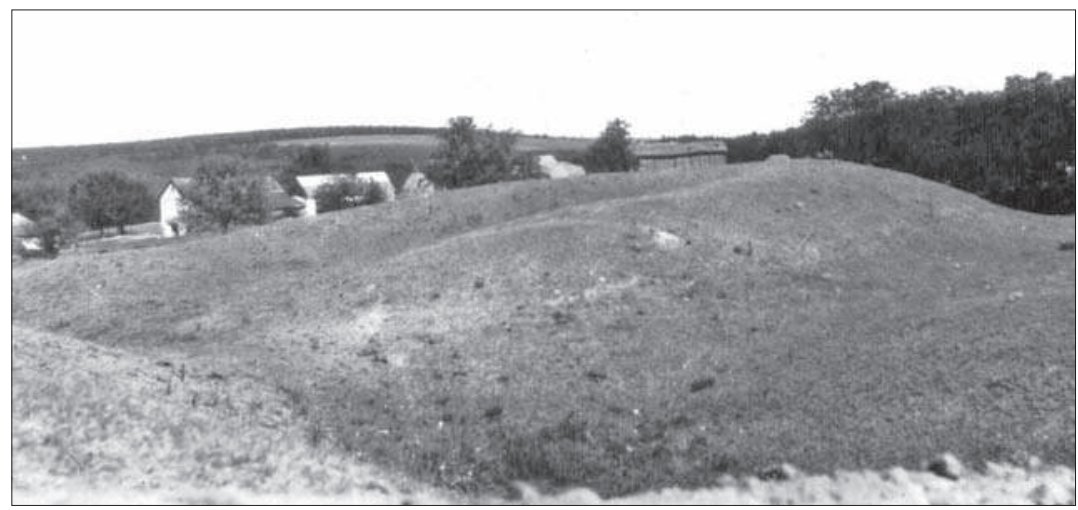

Northern bastion (photo by G. Smirnov)



Central bastion (after Niculiță, Zanoci, Arnăut 2008)

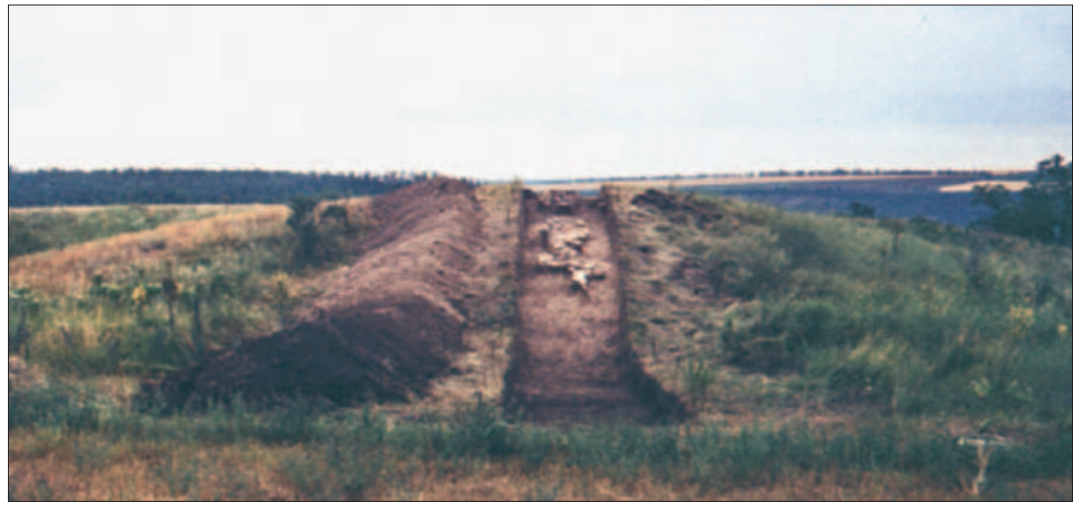

Southern bastion (photo by A. Zanoci)

Fig. 10. Saharna Mare. Bastions of the entrance gates. 


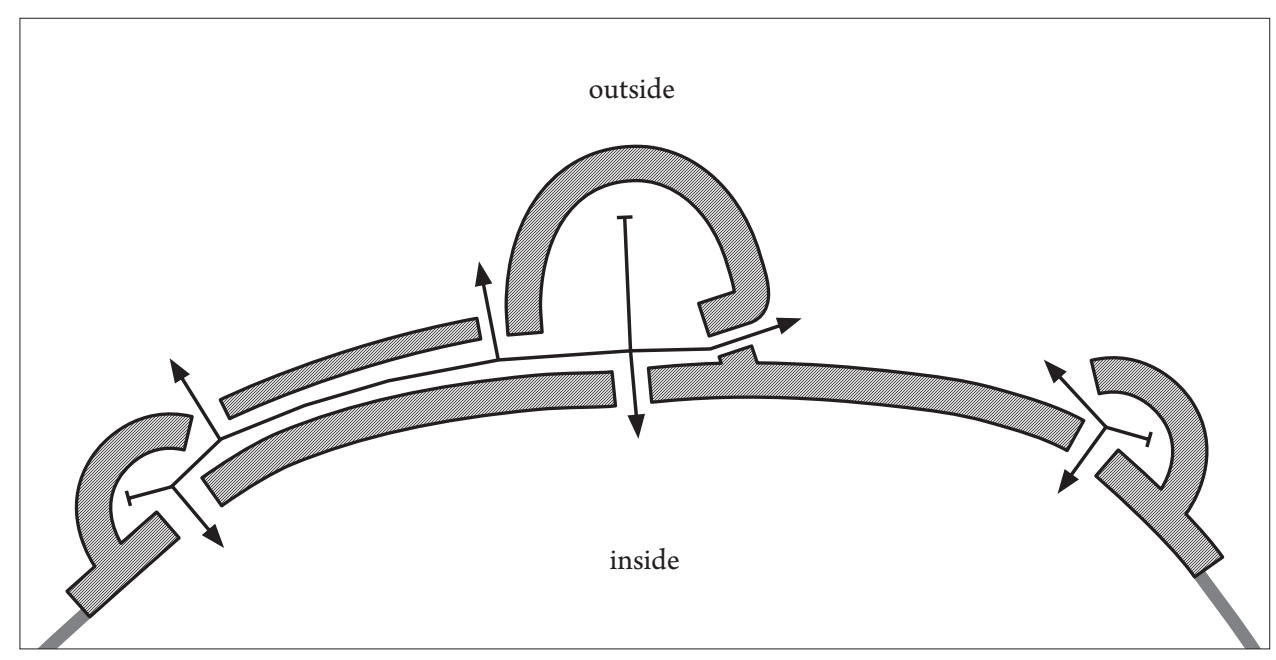

Fig. 11. Saharna Mare. Gates use.

"La Șanț", to the northeast of the gate there is a mound with a diameter of about $25 \mathrm{~m}$ and a height of about 3 $\mathrm{m}$, which can be interpreted as the remains of a "bastion" or of a guard tower (Fig. 13) (Zanoci, Niculiță and Băț 2017, 29, fig. 15). Two towers were erected on both sides of the entrance gate to the Rudi "La Şanţuri" fortress (Romanovskaia 1975, 29). In the Lower Răut region, at Butuceni, a stone wall in the "Hellenistic" style was built in front of the entrance gate

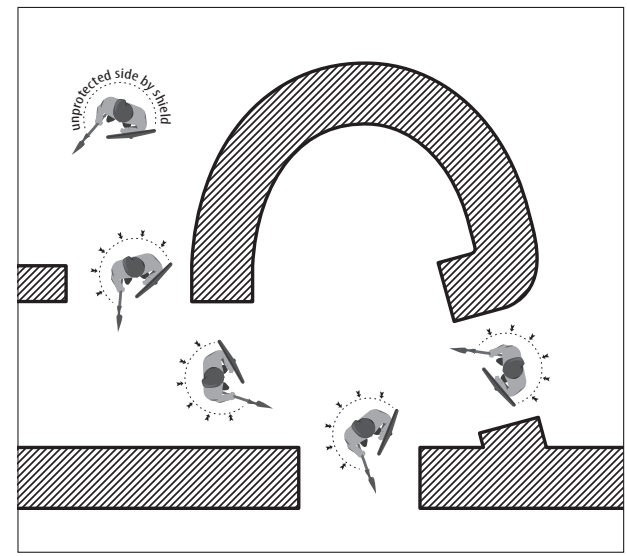

Fig. 12. Saharna Mare. Central gate use. (Niculiță, Teodor and Zanoci 2002, 36, fig. 50, 52, 53).

\section{Bastions located on the perimeter of the fortress (Fig. 21)}

These, as a rule, are integrated into the defensive lines on the most vulnerable sides of the fortifications. They have a semicircular shape with a diameter between 5 and $18 \mathrm{~m}$, being grouped 3-4, located at a distance of about 5-6 m from each other. Currently they have the appearance of ramparts with a base width of about 3-4 $\mathrm{m}$ and a height of about 0.3-0.5 m. Such defensive constructions have been observed in the Saharna micro-zone at the fortifications of Saharna Mare, Saharna "La Vile”, Saharna "La Şanț” I, Saharna "La Şanț” II, 


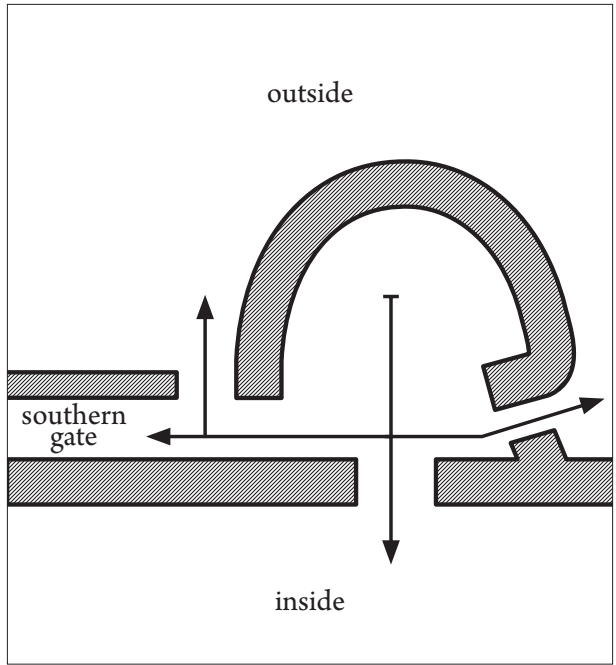

Saharna Mare. Central bastion

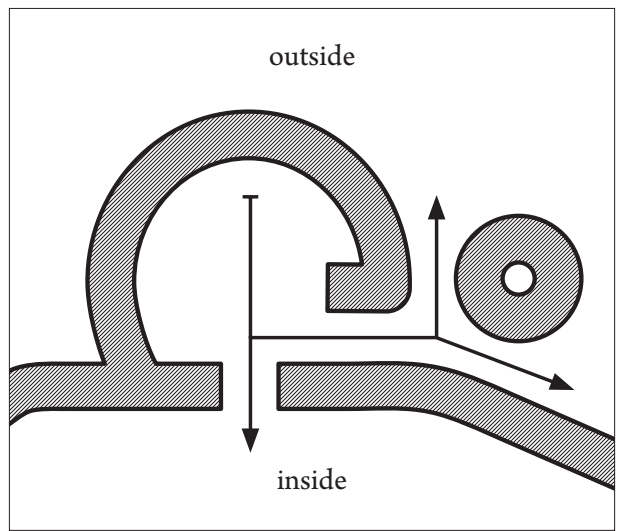

Saharna Mică

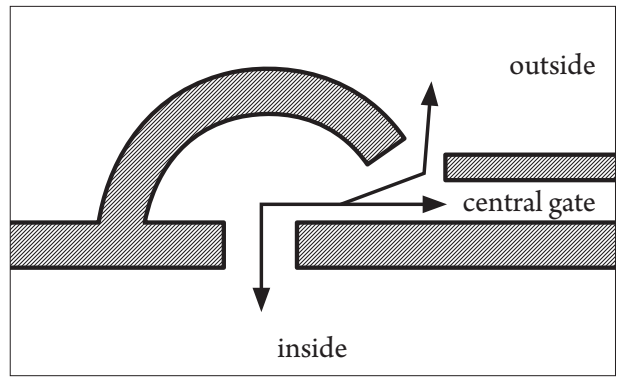

Saharna Mare. Southern bastion

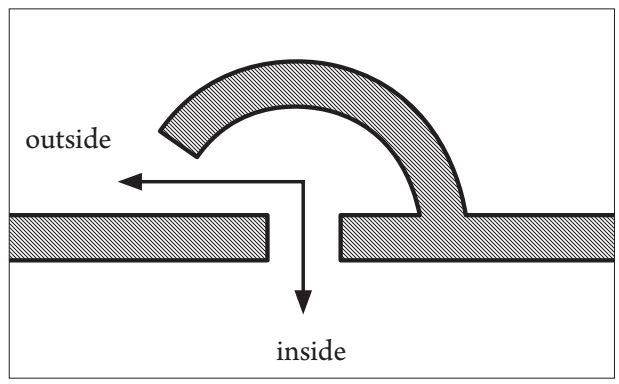

Saharna Mare. Northern bastion

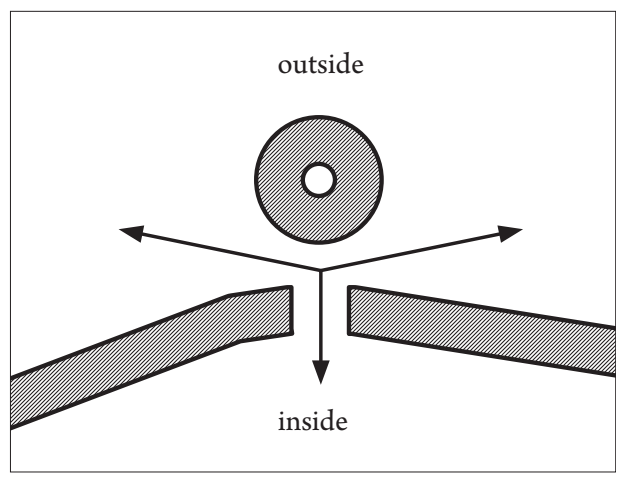

Glinjeni

Fig. 13. Gates with bastions. Schematic plans.

Saharna "Hulboaca", and Ofatinți and in the Horodişte-Ţipova micro-zone - at the site of Horodişte "La Cot".

The Saharna Mare fortification, along with the "wall", the ditch, and the bastions located on the western side, described above, was also defended on the north, east and south sides with a defensive line of the "wall" type that consisted of a wooden framework filled with earth and stones (Niculiță, Zanoci and Băț 2016, 163-171, fig. 109-114). On the east side this "wall” is curved, forming 

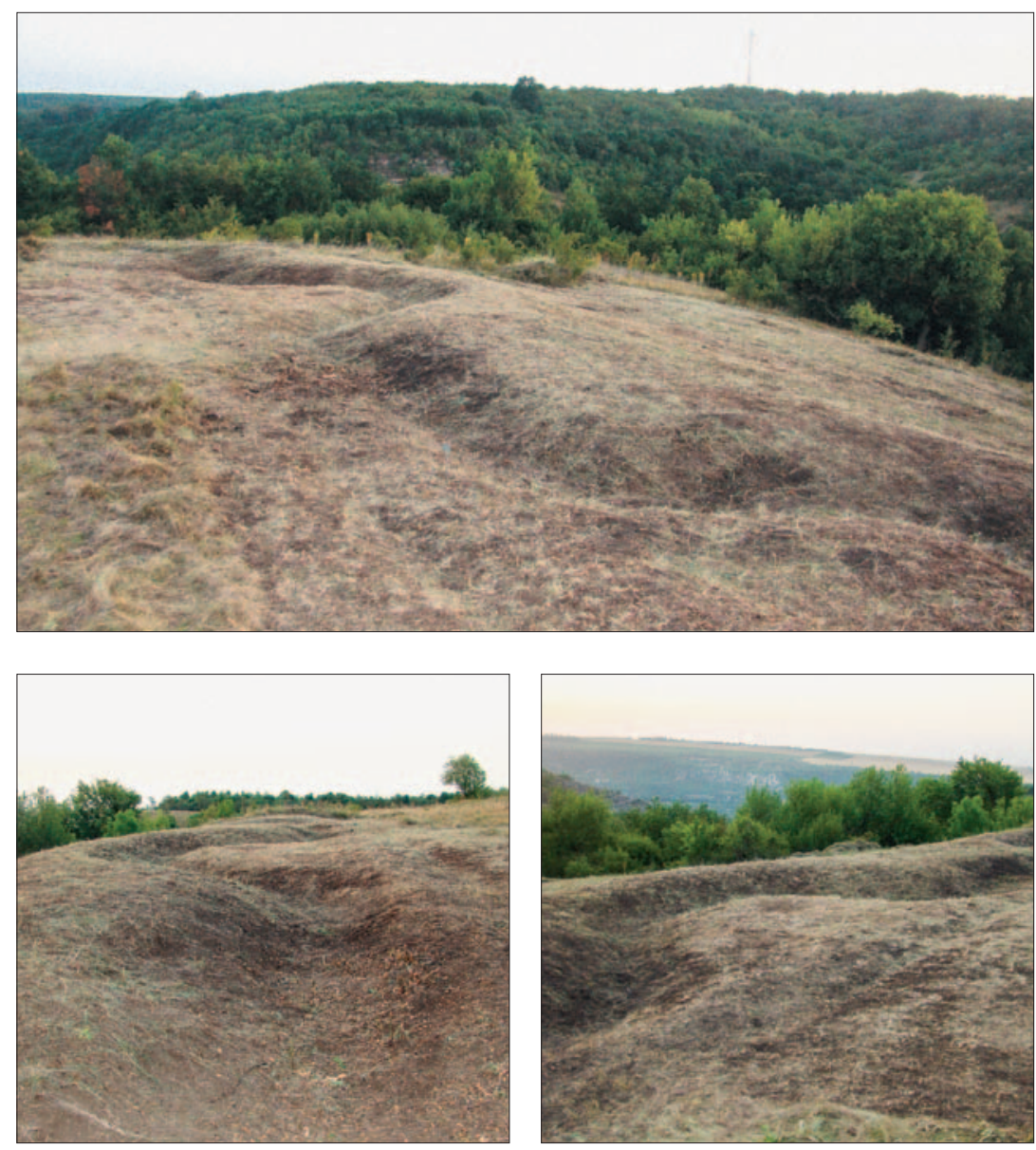

Fig. 14. Saharna Mare. Bastions on the north-eastern flank (after Niculiță, Zanoci and Băț 2016).

eight bastions. They were grouped four at a distance of about $6 \mathrm{~m}$ from each other and were located on the north and south flanks of the fortification (Fig. 8). These defensive constructions have a semi-round shape with a diameter of about 11-12 m, except for those at the northern and southern ends, which are smaller, having $7 \mathrm{~m}$ and $9 \mathrm{~m}$, respectively (Fig. 14).

In order to determine the method of building the bastions at one of them (bastion No. 2) archaeological excavations were carried out. As a result, it was established that the ruins of the building had two layers. The first one has a thickness of about $0.2 \mathrm{~m}$ and is composed of ashen soil, ash and a considerable amount of stones with dimensions between $0.05 \times 0.08 \times 0.10 \mathrm{~m}$ and $0.20 \times 0.30 \times 0.60 \mathrm{~m}$. The second one, with a thickness of about $0.3-0.5 \mathrm{~m}$, consists of burned to red soil, ash, fragments of carbonized beams, and medium size stones $(0.20 \times 0.30 \times 0.50 \mathrm{~m})$. At the base of this layer there were discovered 
three pieces of carbonized beams in the vertical position and two pits of pillars, which formed two rows placed at a distance of about $1 \mathrm{~m}$. The beams were preserved with a diameter of 0.2- $0.3 \mathrm{~m}$ and were at a distance of 0.2-0.4 m from each other. The pits had a cylindrical shape with a diameter of about 0.20-0.25 $\mathrm{m}$ and a depth of $0.15 \mathrm{~m}$. On the contour of the pits there were found stone slabs that were meant to consolidate the pillars dug in them (Niculiță, Zanoci and Băț 2016, fig. 159/2, 3).

The archaeological situation, which was observed in the section that crossed the bastion, shows that it was a "wall", about $1.4 \mathrm{~m}$ wide ${ }^{3}$, of a semicircular shape in plan, about $11 \mathrm{~m}$ in diameter, which consisted of a wooden carcass made of two frames, filled with earth and a considerable amount of stones ${ }^{4}$. Behind the "wall", at a distance of $0.8 \mathrm{~m}$, there was dug a ditch, which repeated the outline of the bastion and had a width of $0.5-0.8 \mathrm{~m}$ and a depth of $0.25 \mathrm{~m}$. Because of its position towards the "wall" and from the modest dimensions of the ditch, it can be assumed that it had the drainage function for the waters flowing from the area of the fortress, which could possibly damage the "wall" (Niculiță, Zanoci and Băț 2016, fig. 11/4).

The fortifications flanking the Saharna Mare site to the north (Saharna "La Vile") and to the south (Saharna "La Şanț" I and Saharna "La Şanț" II) were also defended with similar defensive constructions.

The Saharna "La Vile" fortification (Fig. 4; 15) was located on a promontory with a relative altitude of about $110 \mathrm{~m}$, formed at the junction of the Dniester Valley with a gorge. The inner space of the fortress, with an area of about 0.4 ha, was surrounded by an artificial defensive line, currently in the form of a "rampart" with a base width of about 3-4 $\mathrm{m}$ and a height of about 0.3-0, $4 \mathrm{~m}$. On the east side, the defensive system is corrugated and forms three semi-oval bastions of $18-15 \times 4-5 \mathrm{~m}$ in size, located at a distance of about $6 \mathrm{~m}$ from each other.

In order to clarify the construction system of the bastions, archaeological investigations were carried out at one of them. The remains of the bastion represented a debris layer 0.3-0.6 m thick and $3 \mathrm{~m}$ wide. It consisted of chernozem mixed with ash and stones with dimensions between $0.05 \times 0.1 \times 0.15 \mathrm{~m}$ and $0.15 \times 0.50 \times 0.70 \mathrm{~m}$, some of which were burnt. After the removal of the debris layer, at the depth of about 0.2-0.35 m from the modern ground surface, four pits from the pillars were found. The quasi-cylindrical pits with a diameter of $0.3 \times 0.5 \mathrm{~m}$ and a depth of about $0.2-0.3 \mathrm{~m}$ were arranged in two rows of two pits, oriented north-south. The distance between the rows was about $0.9 \mathrm{~m}$. In

3 To the distance of $1 \mathrm{~m}$ between the frames is added the average thickness of the beams of $0.15-0.20 \mathrm{~m}$.

4 From the investigated part ( $4 \mathrm{~m}$ width), a volume of $7.2 \mathrm{~m}^{3}$ of stones was gathered. 

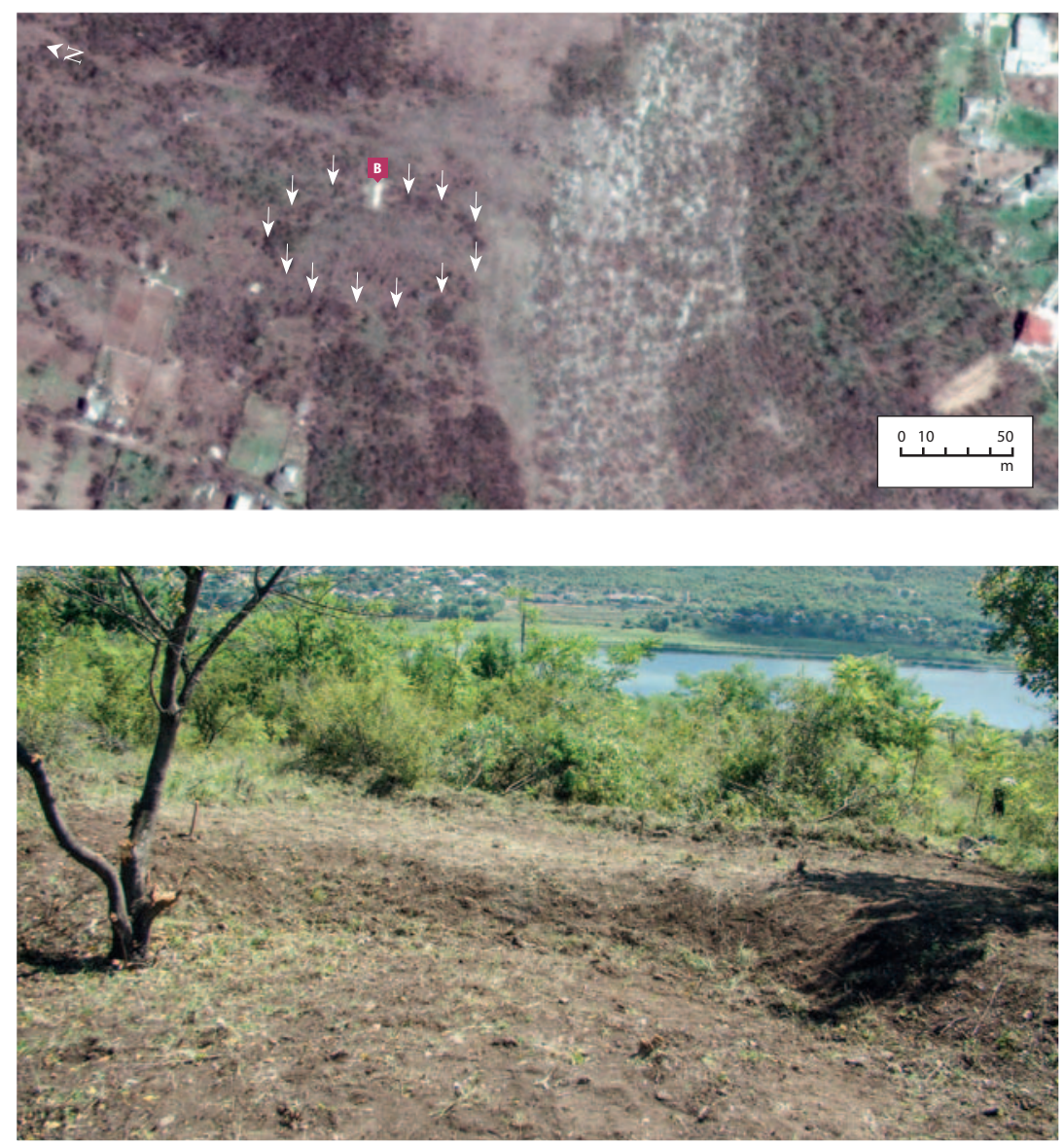

Fig. 15. Saharna "La Vile" (after Niculiță, Zanoci and Băț 2016).

the immediate vicinity of the pits forming the inner row, at a depth of 0.2-0.35 $\mathrm{m}$ from the modern ground surface, a ditch was discovered), which repeated the line of defensive construction. The ditch had a square shape in a section, with a width of $0.70-0.85 \mathrm{~m}$ at the opening and the depth varying between 0.25 and $0.35 \mathrm{~m}$. Because of the configuration of the debris, of the location of the pits, and of the presence of the ditch it can be assumed to be a defensive construction of a "wall" type consisting of two frames of wooden beams, the space between them being filled with earth and stone. Behind it, to protect it from the floods, a ditch for water drainage was dug (Niculiță, Zanoci and Băț 2016, 348-351, fig. 244-246).

The Saharna "La Şanț" I fortification (Fig. 4; 16) was built on a hill of a quasi-polygonal shape, with a relative altitude of about $114 \mathrm{~m}$, which was part of the high and steep bank of the Dniester. It was defended with a circular defensive system that surrounded an area of about 0.8 ha. The remains of the de- 

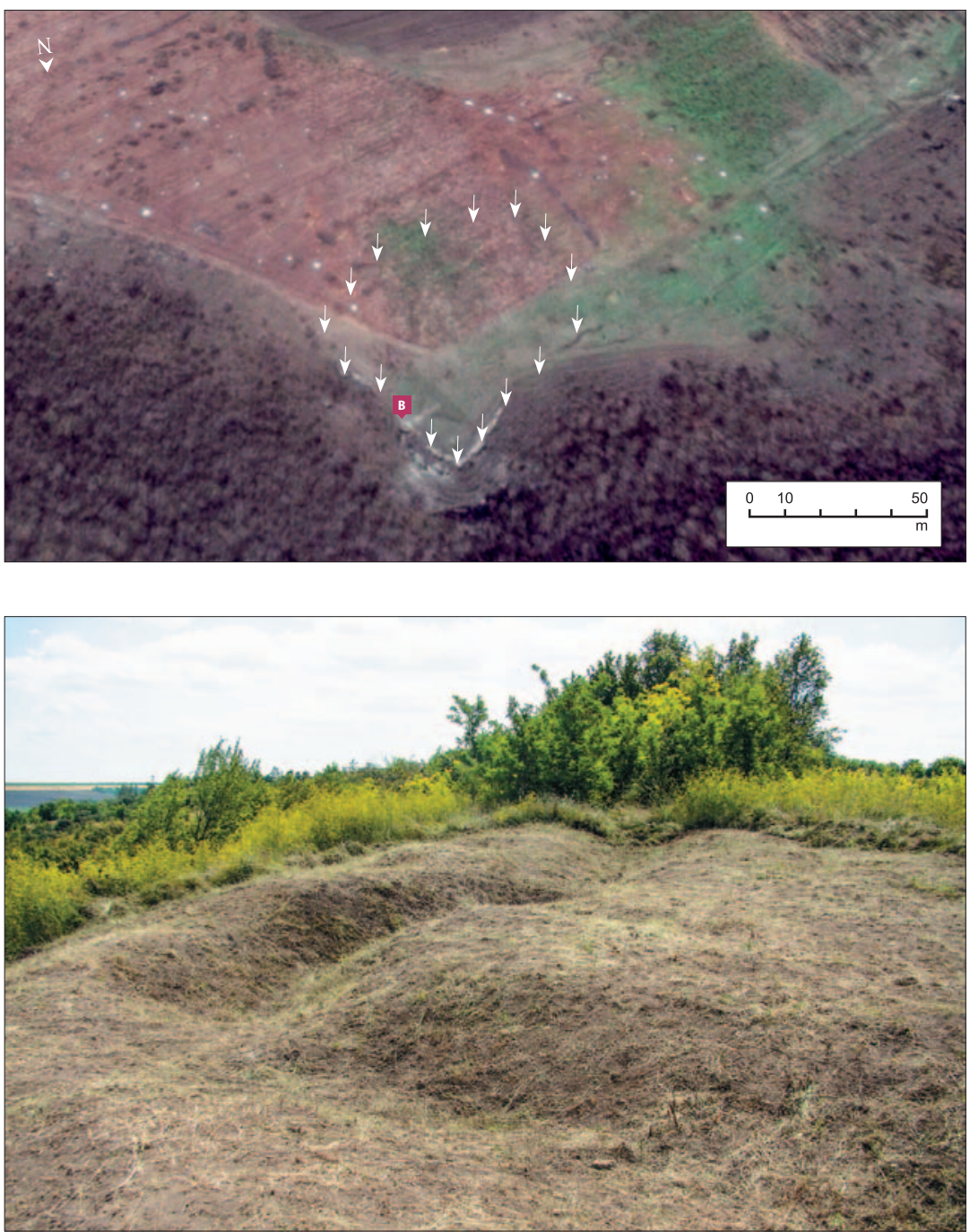

Fig. 16. Saharna "La Șanț"I (after Niculiță, Zanoci and Băț 2016).

fensive constructions are in the form of a "rampart" with a base width of about 3-4 $\mathrm{m}$ and a height of about 0.4-0.5 m. There were three bastions on the north side and three ones on the east side in the defensive line; the bastions were of semi-round shape, with a diameter of about 9-10 m, the distance between them being about 6-7 m. In order to identify the way of construction of the bastions, archaeological investigations were carried out at one of them. Remains of the bastion were found at a depth of $0.3 \mathrm{~m}$ from the modern ground surface; they represented an agglomeration with a thickness of about 0.7-0.9 m formed of ashen clayey soil, stones and fragments of carbonized beams. Under the debris layer there were found four pits from the pillars, arranged in two rows, located 
at a distance of $1 \mathrm{~m}$ from each other. The pits had a diameter of $0.3-0.4 \mathrm{~m}$ and a depth of about $0.25-0.56 \mathrm{~m}$. On the outline of a pit, four limestone stones were identified, which probably served to strengthen the pillar.

Behind the remains of the bastion, there was discovered a small ditch dug in the rock, with a width of 0.8-0.9 $\mathrm{m}$ and a depth of 0.3-0.4 $\mathrm{m}$, filled with ashcolored soil, stones, and carbonized wood fragments.

From the archaeological situation on the researched part, it can be seen that there was a semi-circular defensive structure, consisting of a "wall" made of two frames of wooden beams, with a width of about $1.4 \mathrm{~m}$, filled with earth and stone $^{5}$. Behind the "wall" a water drainage ditch was dug, similar to the ones discovered in Saharna Mare, Saharna "La Vile", and so on (Niculiță, Zanoci and Băţ 2016, 354-358, fig. 250-253).

The Saharna "La Şanț" II fortification was located about $250 \mathrm{~m}$ southeast of the previous one and also occupies a hilltop, which rises above the Dniester valley by about $112 \mathrm{~m}$ (Fig. 4; 17). The quasi-triangular shaped area of about 0.12 ha was surrounded by an artificial defensive system that currently has the shape of a "rampart" with a base width of about $4 \mathrm{~m}$ and a height of about 0.3$0.4 \mathrm{~m}$. The defensive line on the eastern side includes four half-round bastions with a diameter of about $5 \mathrm{~m}$, at a distance of about $6 \mathrm{~m}$ from each other. Four other bastions were found on the northern edge of the promontory. These, unlike those on the eastern side and the bastions of the Saharna Mare, Saharna "La Vile" and Saharna "La Şanț" I, which were arched outward, were concave inwards. The remains of the bastions at the time of the discovery had a semioval shape with the dimensions of $4.0 \times 2.5 \mathrm{~m}$ and were at a distance of about 7 $\mathrm{m}$ from each other. To study the technique of construction of the bastions on the northern side, an archaeological section was made on one of them. In the course of investigation there was discovered an agglomeration of stones measuring $0.2 \times 0.15 \times 0.1-0.4 \times 0,3 \times 0.15 \mathrm{~m}$ mixed with ash soil, under which four cylindrical pits with a diameter of $0.2-0.3 \mathrm{~m}$ and a depth of $0.2-0.3 \mathrm{~m}$ were found. Two of them were arranged on a line oriented east-west, and two others on the north-south axis. As they were arranged, they were supposed to be part of a defensive construction. Pit I and pit II belonged to the construction of the "wall" of the fortress and pit III and pit IV belonged to the construction of the bastion.

As a result of the archaeological researches, the remains of a ditch were also found. On the investigated plot it represented a right angle. On the eastern side of the section, the ditch had a length of $3.8 \mathrm{~m}$, and then turned westward, being observed at the entire width of the excavation $(2 \mathrm{~m})$. The ditch had a width of

5 On the investigated area, about $0.8 \mathrm{~m}^{3}$ of limestone was collected from the "wall" filling. 

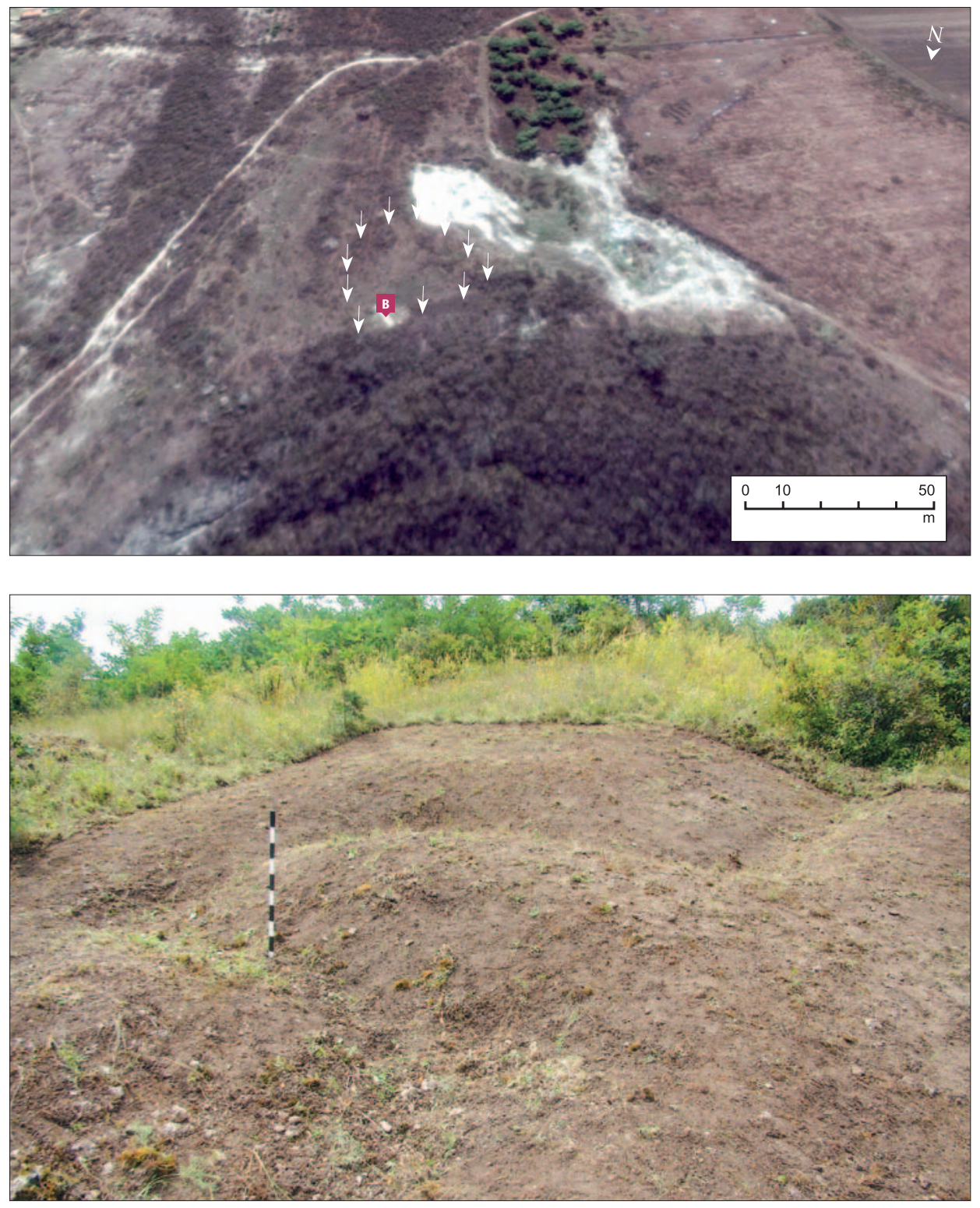

Fig. 17. Saharna “La Șanț” II (after Niculiță, Zanoci and Băț 2016).

about $0.6 \mathrm{~m}$ and a depth of $0.5 \mathrm{~m}$ (Niculiță, Zanoci and Băț 2016, 358-311, fig. 254, 255).

Because of the configuration of the remains of the defensive structure, the location of the pits, as well as the ditch route, the existence of a "wall" built from a wooden framework filled with earth and stone is assumed on this side. Behind the "wall", from the inside, a bastion was built that seems to have had 


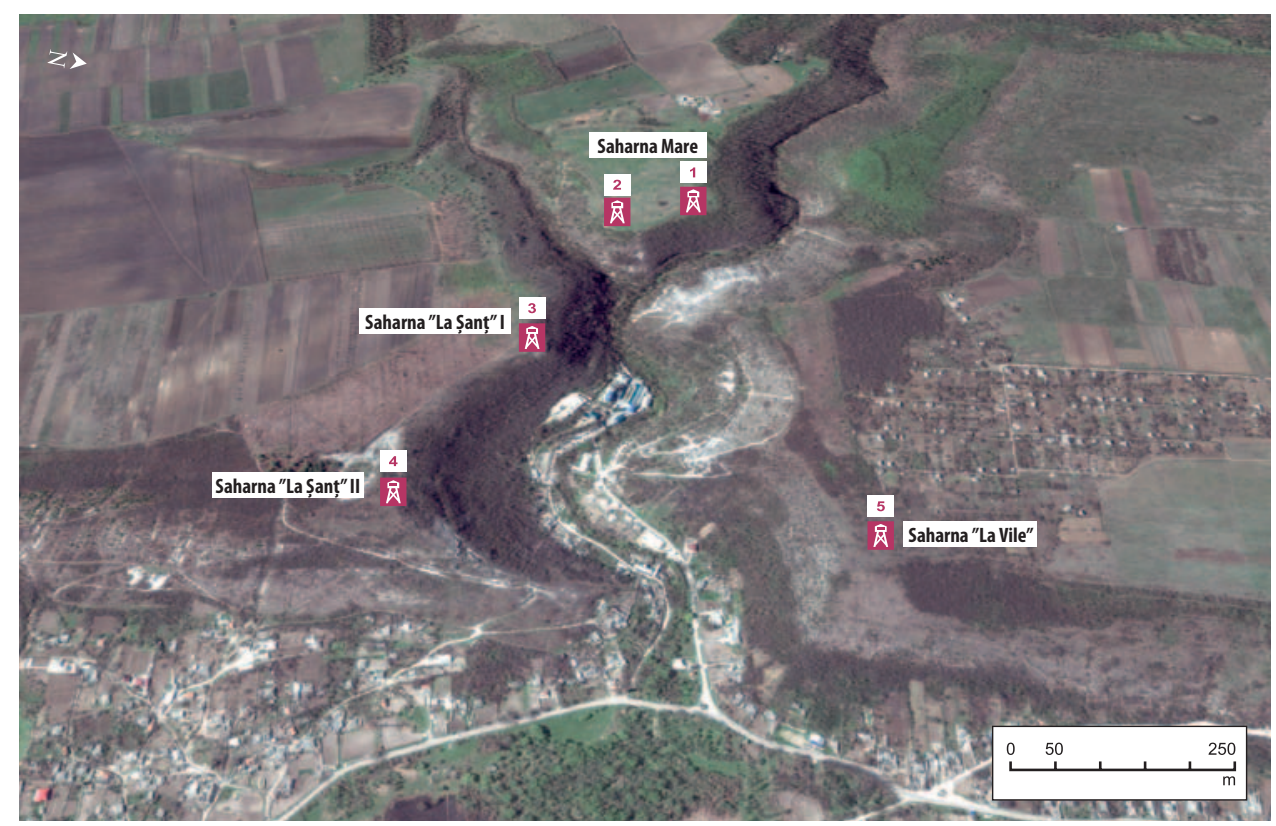

Fig. 18. Visual surveillance in the "Valea Crac" gorge (after Google Earth Pro).

a quadrilateral shape. Behind the "wall" and the bastion a small ditch was dug that was used to drain the water.

Another fortress with bastions built in the defensive "wall" was studied in the Horodişte-T,ipova micro-zone located about $5 \mathrm{~km}$ downstream the Dniester, at Horodişte "La Cot" (Fig. 5). The site, with an area of about 28 ha, is located on a quasi-polygonal promontory with a relative altitude of $65 \mathrm{~m}$, bounded on three sides by gorges with relatively steep slopes (Fig. 19). The fortress was surrounded by a "rampart" with a total length of about $2.5 \mathrm{~km}$, doubled on the western side by a defense ditch. On the eastern and southern sides the "rampart" is curved, forming a series of bastions. 21 bastions could be found on the eastern side and about 12 ones - on the southern side. They have arched shape, with an opening of about 10-12 $\mathrm{m}$. The ruins of the bastions are present in the form of a "rampart" with a base width of about $3 \mathrm{~m}$ and a height of about $0.4 \mathrm{~m}$ (Fig. 20).

In order to clarify the construction technique and the time of building of the bastions, archaeological research was carried out at the eastern end of the defensive line on the southern side. Remains of the defensive construction appeared at a depth of $0.5 \mathrm{~m}$ from the modern ground surface and presented as debris composed of clayey soil mixed with ash, carbonized wood fragments and pieces of burnt clay. It had a concave shape and was found on a $2.7 \mathrm{~m}$ wide space, 


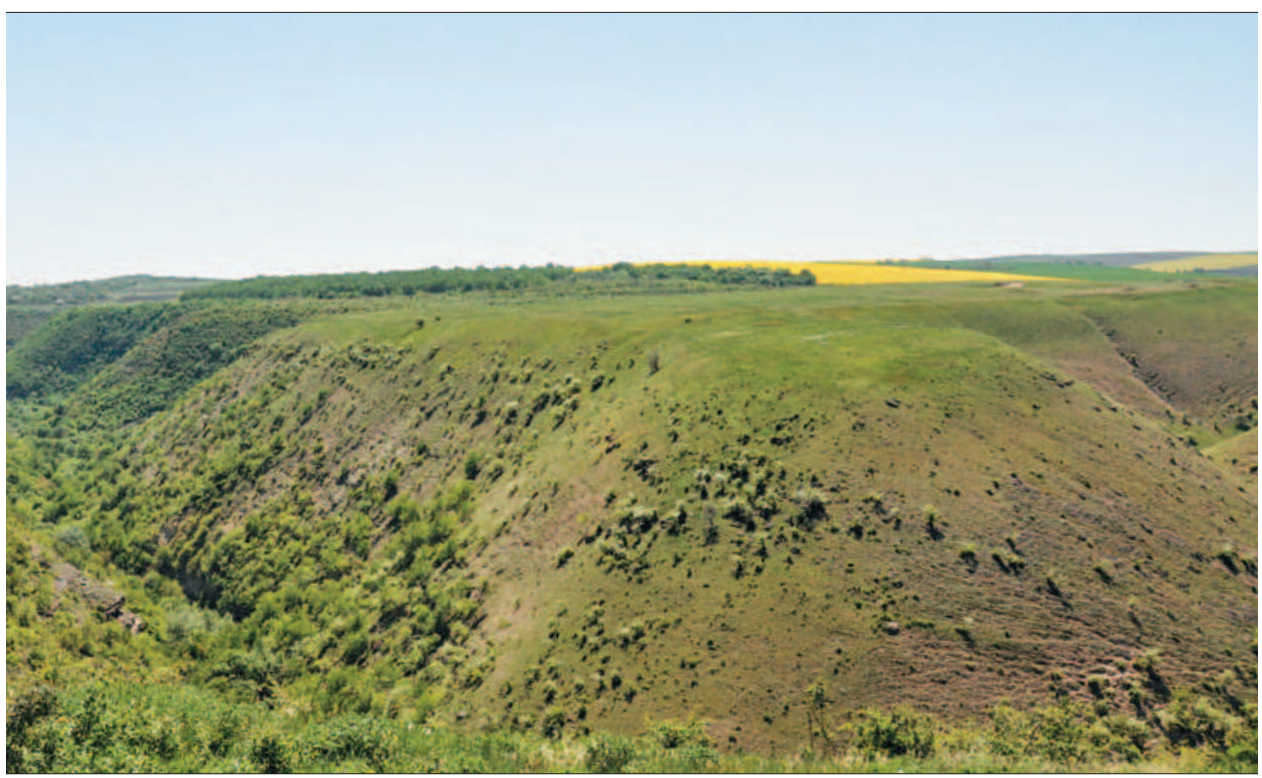

Fig. 19. Promontory of the Horodiște "La Cot" fortification (after Zanoci, Niculiță and Băț 2015).

reaching a maximum thickness of $0.55 \mathrm{~m}$. Within the debris there is a large stone $(1.2 \times 0.6 \times 0.3 \mathrm{~m})$ and several small pieces of limestone $(0.15 \times 0.10 \times 0.05$ $\mathrm{m})$. Also, among the ruins, at a depth of about $0.7 \mathrm{~m}$ a carbonized beam was discovered in situ. It was in the vertical position and was $0.15 \mathrm{~m}$ in diameter and $0.3 \mathrm{~m}$ long. Many pieces of carbonized wood were found around it.

At the northern end of the debris agglomeration, in the east and west profiles the traces of two pits from pillars were found. They were about $0.4 \mathrm{~m}$ in diameter and their bases were buried in the ground about $0.1 \mathrm{~m}$ from the ancient ground surface (bottom level of the debris). The pits were filled with burnt soil mixed with carbonized wood pigments. Under the debris agglomeration, over its entire width, a layer of soil, about $0.1 \mathrm{~m}$ thick, burned to red was discovered.

From the archaeological situation, it was assumed that the excavated debris represents the ruins of a defensive line. It consisted of two rows of pillars. The first is confirmed by the presence of the pits observed in the profile. The second is indicated by the carbonized beam in situ. The distance between the rows is estimated at about $0.6 \mathrm{~m}$, to which is added the thickness of the beams of about 0.2-0.3 m, thus the defensive construction had a total width of about 1.0-1.2 $\mathrm{m}$. The space between the rows of beams was filled with earth and stones. It is not excluded that the exterior surface of this structures had been covered with clay, which is suggested by fragments of burnt clay found in the debris. As a 

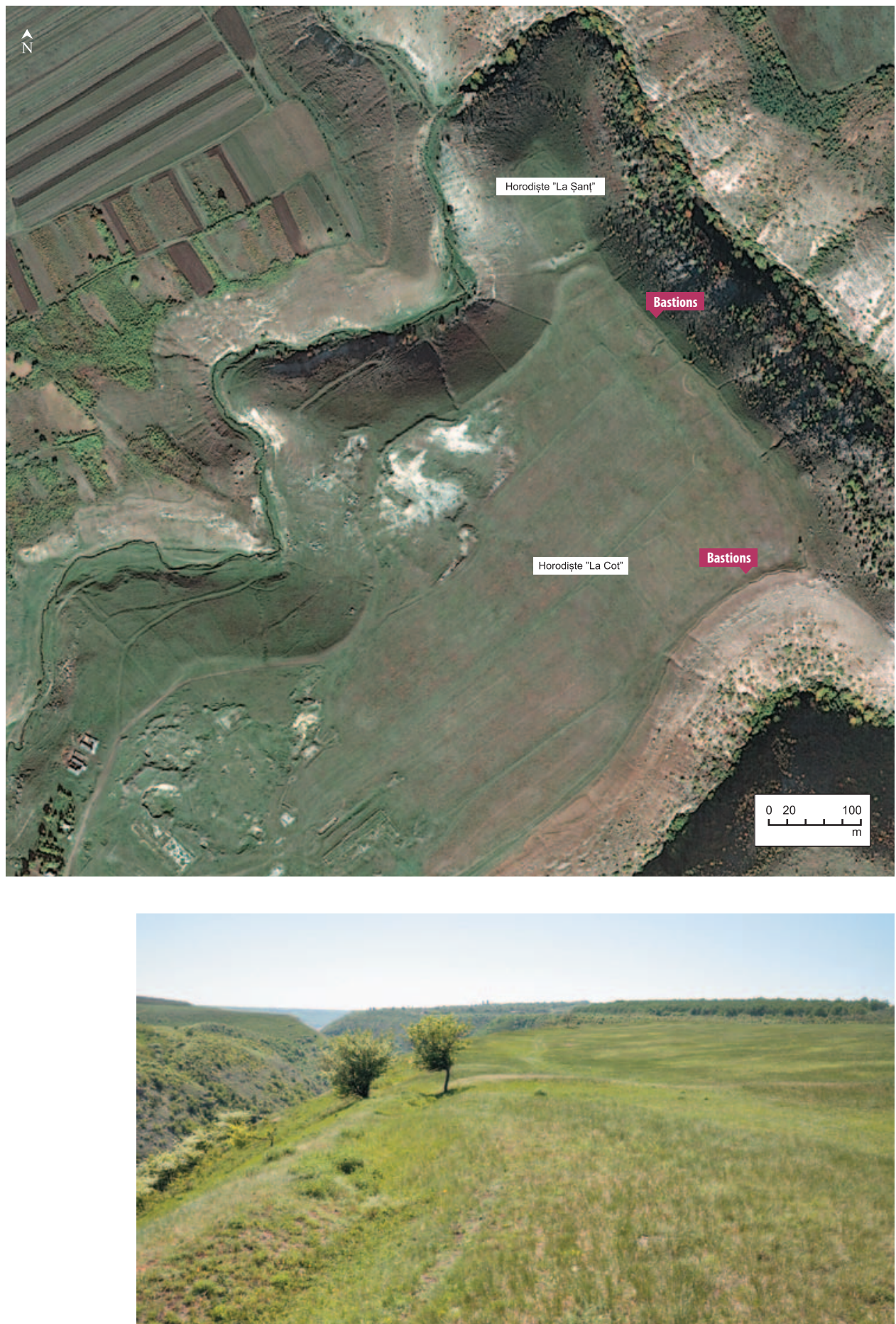

Fig. 20. Horodiște "La Cot" (after Zanoci, Niculiță and Băț 2015). 


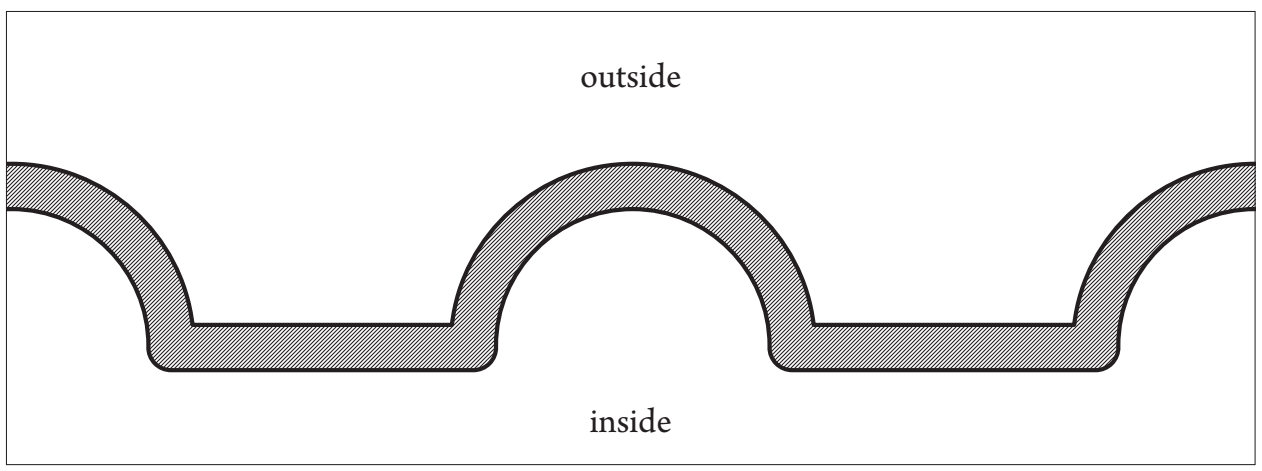

Saharna Mare

Saharna "La Șanț" I

Saharna "La Vile"

Ofatinţi

Saharna "Hulboaca"

Horodiște "La Șanț"

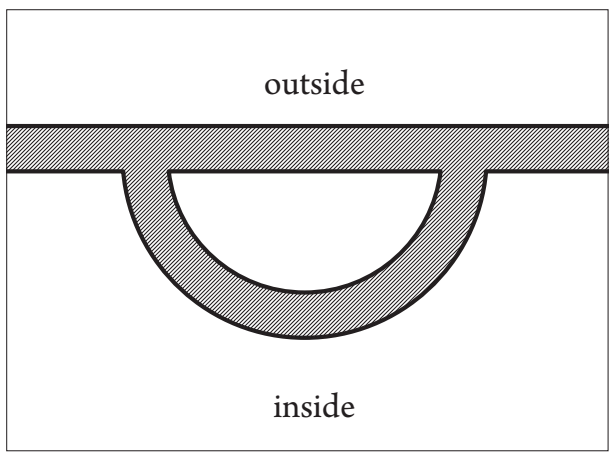

- Saharna "La Șanț" II

Fig. 21. Bastions located on the perimeter of the fortress. Schematic plans.

result of violent destruction, the defensive construction collapsed to the south (towards the edge of the promontory), which caused the red-burning of the soil (the ancient ground surface) over which it fell (Niculiță, Zanoci and Băț 2014, 235-239, fig. 3, 4; Zanoci, Niculiță and Băț 2015, 82-88, fig. 4-6).

Thus, after studying the placement of the bastions integrated into the defense lines, it was observed that they were, in most cases, arranged on the eastern sides of the fortresses, being oriented towards the Dniester River. They were also found on the edges of the gorges, which go from the Dniester to the interior of the territory. These sectors (eastern, southern, and northern) of the fortifications were most exposed to possible attacks, which could come from communities living east of the Dniester. Probably for these reasons, for better surveillance of the enemy's movement, the defensive lines on these sides were supplemented with semicircular bastions (Fig. 18).

The presence of defensive constructions of the bastion type, no matter where they are located, denotes the fact that the Getic communities in the Middle Dniester region had a thorough knowledge in the field of military architecture and strategy. 


\section{Bibliography}

Asăndulesei, Andrei. 2016. „Investigații non-invazive”. In Evoluţia habitatului din microzona Saharna în epoca fierului edited by Ion Niculiță, Aurel Zanoci, and Mihail Băț, 34-39. Chişinău: Cartdidact.

Ciobotaru, Valerian. 2014. „Aspecte geologice generale”. In Aşezarea şi necropola din prima epocă a fierului Saharna-Țiglău, edited by Ion Niculiță and Andrei Nicic, 11-13. Chişinău: Bons Offices.

Goltseva N.V., and M.T. Kashuba. 1995. Glinzhen II. Mnogosloinyi pamiatnik Srednego Podnesnrovia. Tiraspol: Mako.

Ivanova, Mariya. 2008. Befestigte Siedlungen auf dem Balkan, in der Ägäis und in Westanatolien, ca. 5000-2000 v. Chr. Münster: Waxmann.

Kašuba, Maia, Vasile Haheu, and Oleg Levițki. 2000. Vestigii traco-getice pe Nistrul Mijlociu. Bucureşti.

Keeley, Lawrence H., Marisa Fontana, and Russell Quiq. 2007. „Baffles and Bastions: The Universal Features of Fortifications". Journal of Archeological Research 15/1: 55-95.

Niculiță, Ion, Aurel Zanoci, Mihail Băț, and Sergiu Matveev. 2013. „Investigațiile arheologice la situl Saharna Mare (2009-2012) (II)”. Tyragetia s.n. VII/1: 219-292.

Niculiță, Ion, Silvia Teodor, and Aurel Zanoci. 2002. Butuceni. Monografie arheologică. Bucureşti: Vavila Edinf.

Niculiță, Ion, Aurel Zanoci, and Tudor Arnăut. 2008. Habitatul din mileniul I a. Chr. în regiunea Nistrului Mijlociu (siturile din zona Saharna). Chişinău: Bons Offices.

Niculiță, Ion, Aurel Zanoci, and Mihail Băț. 2013. „Diachronic evolution of sites from Saharna area, the region of Middle Dniester". In The Thracians and their Neighbors in the Bronze and Iron Ages. Proceedings of the $12^{\text {th }}$ International Congress of Thracology (Târgovişte, $10^{\text {th }}-14^{\text {th }}$ September 2013), edited by Cristian Schuster, Ovidiu Cîrstina, Marian Cosac, and George Murătoreanu, vol. I, 295-314. Târgovişte.

Niculiță, Ion, Aurel Zanoci, and Mihail Băţ. 2014. „Cercetări geospațiale şi arheologice în microzona Horodişte-Ţipova”. Tyragetia s.n. VIII/1: 235-252.

Niculiță, Ion, Aurel Zanoci, and Mihail Băț. 2016. Evoluția habitatului din microzona Saharna în epoca fierului. Chișinău: Cartdidact. 
Revenco, Marcel, Tudor Castraveț, and Ionuț Cristi Nicu. 2016. „Microzona Saharna. Caracterizare geografică”. In Evoluția habitatului din microzona Saharna în epoca fierului edited by Ion Niculiță, Aurel Zanoci, and Mihail Băț, 9-18. Chişinău: Cartdidact.

Romanovskaia, M.A. 1975. „Oboronitelnye sooruzheniia gorodishcha Rudi”. In Noveishie otkryia sovetskih arheologov, II, 29-31. Kiev.

Sîrbu, Valeriu, and George Trohani. 1997. „Cités et établissements fortifiés entre les Carpates Meridionales, le Danube et la Mer Noire (Ve-IIIe siècles av. J.-C.)". In The Thracian World at the Crossroads of Civilisations. Proceedings of the Seventh International Congress of Thracology, Constanța-Mangalia-Tulcea, 20-26 May 1996, I, 512-539. Bucharest.

Smirnov, G.D. 1953. Otchetnye materialy po arheologicheskim issledovaniiam Moldavii za 1946-1953 gody. Kishinev. Arhiva MNIM, inv. nr. 507.

Vitruvius. 1914. The ten books on architecture. Translated by Morris Hicky Morgan. Harvard: University press.

Zanoci, Aurel. 1998. Fortificațiile geto-dacice din spațiul extracarpatic în secolele VI-III a. Chr. Bucureşti: Vavila Edinf.

Zanoci, Aurel. 2015. „Typology and evolution of gates and access into early hallstattian fortresses in Tisa-Dniester space”. Tyragetia s.n. IX/1: 7-27.

Zanoci, Aurel, and Mihail Băţ. 2011. „Spreading of sites of XII ${ }^{\text {th }} / \mathrm{XI}^{\mathrm{th}}-\mathrm{III}^{\mathrm{rd}}$ centuries B.C. in the Middle Dniestr basin”. Carpatica 40: 15-39.

Zanoci, Aurel, Ion Niculiță, and Mihail Băț. 2015. „Fortifications and open settlements of the 1st millennium BC in the micro-zone of Horodişte-Țipova”. In Fortified sites from the $1^{\text {st }}$ millennium BC in Central and South-Eastern Europe. Materials of the Moldovan-Romanian-German Colloquium (Saharna, July $\left.24^{\text {th }}-26^{\text {th }}, 2014\right)$, edited by Aurel Zanoci, Peter Ettel, and Mihail Băţ, 81-100. Chişinău: Bons Offices.

Zanoci, Aurel, Ion Niculiță, and Mihail Băț. 2016. „Situri fortificate din microzona Țahnăuți - Țareuca - Rezina”. In Sesiunea științifică a Departamentului Istoria Românilor, Universală și Arheologie (Chișinău, 13 mai 2016). Rezumatele comunicărilor, 21-22. Chișinău.

Zanoci, Aurel, Ion Niculiță, and Mihail Băț. 2017. „Situri din epoca fierului în bazinul râului Ciorna / Iron Ages sites in the Ciorna River basin”. In Iron Age fortifications on the Tisa-Dniestr spase. Proceedings of Saharna Summer Colloquium (July $14^{\text {th }}-17^{\text {th }}, 2016$ ), edited by Aurel Zanoci, Valeriu Sîrbu, and Mihail Băț, 7-46. Chişinău-Brăila: Istros. 


\section{Particularitățile fortificațiilor getice din regiunea Nistrului Mijlociu (microzonele Saharna și Horodiște-Țipova)}

Rezumat: În regiunea Nistrului Mijlociu, în urma cercetărilor de teren, a sondajelor și a cercetărilor arheologice au fost repertoriate 40 de fortificații și 70 așezări deschise, atribuite comunităţilor getice din sec. IV-III a. Chr. În ultimii ani o atenție sporită a fost acordată cercetării fortificațiilor din microzonele Saharna (16 situri) și Horodiște-Ţipova (7 situri). În urma cercetărilor de teren și a investigațiilor arheologice s-a observat că sistemul defensiv al fortificațiilor din această regiune are unele particularități, care nu sunt atestate la restul cetăților getice. Printre aceste se evidențiază prezența așa-numitelor „bastioane”, care după locul de amenajare în cadrul sistemului defensiv pot fi împărțite în două tipuri: bastioane amplasate în fața porților de intrare și „bastioane” amplasate pe perimetrul fortificației. Edificarea construcțiilor defensive de tip bastion, ca elemente suplimentare a fortificațiilor, denotă faptul că comunitățile getice din regiunea Nistrului Mijlociu posedau cunoștințe temeinice în domeniul arhitecturii militare.

Cuvinte-cheie: regiunea Nistrului Mijlociu, epoca fierului, geți, fortificații, bastioane.

ZANOCI Aurel, Moldova State University. e-mail: azanoci@gmail.com BĂȚ Mihail, Moldova State University. e-mail: mb_usm@yahoo.com 